\title{
The Relationship Between the Activity Level, Internet Addiction, and Depressive Symptoms of University Students During the Coronavirus Disease-2019 Outbreak Cross-Sectional Study
} Koronavirüs Hastalı̆̆ı-2019 Salgınında Üniversite Öğrencilerinin
Aktivite Düzeyi, Internet Bağımlılığı ve Depresif Belirtiler ile
İlişkisi: Kesitsel Çalışma (D) Nazan Öztürk ${ }^{1}$, (D) Emine Gerçek Öter ${ }^{2}$, (D) Filiz Abacıgil ${ }^{3}$

${ }^{1}$ Aydın Adnan Menderes University, Söke Vocational School of Health Services, Home Care Services Program, Aydın, Turkey

${ }^{2}$ Aydın Adnan Menderes University Faculty of Nursing, Department of Gynaecology and Obstetric Nursing, Aydın, Turkey

${ }^{3}$ Aydın Adnan Menderes University Faculty of Medicine, Department of Public Health, Aydın, Turkey

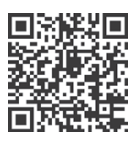

Keywords

Physical activity, internet addiction, depressive symptoms, COVID-19 outbreak, university student

Anahtar Kelimeler

Fiziksel aktivite, internet bağımlılığı, depresif belirtiler, COVID-19 salgını, üniversite öğrencisi

Received/Geliş Tarihi : 29.06.2021

Accepted/Kabul Tarihi : 23.08.2021

doi:10.4274/meandros.galenos.2021.70457

Address for Correspondence/Yazışma Adresi: Nazan Öztürk Ph.D.,

Aydın Adnan Menderes University, Söke Vocational School of Health Services, Home Care Services Program, Aydın, Turkey Phone : +90 5066271852

E-mail : nazan.ozturk@adu.edu.tr

ORCID ID: orcid.org/0000-0002-7510-4336

(C) Meandros Medical and Dental Journal, Published by Galenos Publishing House.

This is article distributed under the terms of the

Creative Commons Attribution NonCommercial 4.0

International Licence (CC BY-NC 4.0).

\begin{abstract}
Objective: The coronavirus disease-2019 (COVID-19) pandemic significantly disrupted normal activities globally. Social restriction measures were encountered during the pandemic process, which resulted in students staying at home for a long time. This study aimed to investigate the relationship between physical activity, internet addiction, and depressive symptoms of university students during the COVID-19 pandemic.

Materials and Methods: This cross-sectional study was conducted with 160 students studying at Aydın Adnan Menderes University Söke Health Services Vocational School between July and August 2020. A Personal Identification Form, Short Form of Young's Internet Addiction Test, Beck Depression Scale, and International Physical Activity Questionnaire (IPAQ) were used to collect the research data. Spearman correlation test and Student's t-test were used for data analysis.

Results: The IPAO revealed that $28.2 \%$ of the students were active. The students' mean depression scores were $8.8 \pm 6.6(0-37)$ and the internet addiction mean score was $25.1 \pm 7.2(12-47)$. A moderately significant positive correlation was found between the mean scores of internet addiction and depressive symptoms ( $r=0.303$; $p<0.01$ ). No difference was found between the mean scores of depressive symptoms and internet addiction in active and inactive students ( $p>0.05)$. Contrarily, a relationship was determined between internet addiction and depressive symptoms. Conclusion: Improving the physical and psychological health of university students during the pandemic process is important for public health. Therefore, various multi-sectoral approach developments, such as online physical activity programs, are recommended. Additionally, students should be made aware of how to balance the time spent in front of the computer or the internet.
\end{abstract}


Öz

Amaç: Koronavirüs hastalığı-2019 (COVID-19) pandemisi, küresel olarak normal aktiviteleri önemli ölçüde bozmuştur. Pandemi sürecinde karşımıza çıkan sosyal kısıtlama önlemleri öğrencilerin uzun süre evde kalmasını gerekli kılmıştır. Çalışmanın amacı, COVID-19 pandemisinde üniversite öğrencilerinde fiziksel aktivite düzeyi, internet bağımlılığı ve depresif belirtiler arasındaki ilişkiyi incelemektir.

Gereç ve Yöntemler: Bu kesitsel çalışma, Temmuz ve Ağustos 2020 tarihleri arasında Aydın Adnan Menderes Üniversitesi Söke Sağlık Hizmetleri Meslek Yüksekokulu'nda okuyan 160 öğrenci ile yapıldı. Araştırma verileri Birey Tanıtım Formu, Young İnternet Bağımlılığı Testi Kısa Formu, Beck Depresyon Ölçeği ve Uluslararası Fiziksel Aktivite Anketi (IPAQ) kullanılarak toplandı. Veri analizi için Spearman korelasyon testi ve Student's t-testi kullanıldı.

Bulgular: Öğrencilerin \%28,2'sinin IPAQ'a göre aktif olduğu belirlendi. Öğrencilerin depresyon puan ortalamaları 8,8 $\pm 6,6$ (0-37),

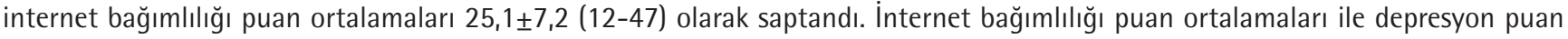
ortalamaları arasında pozitif yönde orta derecede anlamlı bir ilişki tespit edildi $(r=0,303 ; p<0,01)$. Aktif olan öğrenciler ile inaktif olanlar karşılaştııılığında depresyon ve internet bağımlıı̆ı puan ortalamaları arasında fark bulunmadı $(p>0,05)$. Buna karşın internet bağımlıı̆̆ı ile depresif belirtiler arasında ilişki olduğu belirlendi.

Sonuç: Pandemi sürecinde üniversite öğrencilerinin fiziksel ve psikolojik sağlık durumlarını geliştirmek halk sağlığı açısından önemlidir. Bunun için online fiziksel aktivite programları gibi çeşitli çok sektörlü yaklaşımların geliştirilmesi önerilmektedir. Ayrıca bilgisayar ya da internet başında geçirilen sürenin dengeli olması konusunda öğrenciler bilinçlendirilmelidir.

\section{Introduction}

Coronavirus disease-2019 (COVID-19) emerged in Wuhan, China in December 2019 and started to spread rapidly in many countries (1). COVID-19 is not only a health problem, but it also brings about serious economic, educational, and social consequences. Understanding the behavioral and mental health consequences of this crisis is critical in order to be ready for future pandemics. There have been changes in the mental health levels around the world during the COVID-19 pandemic $(2,3)$.

University students are a particular social group that is under pressure from all aspects in their daily life, educational life, and emotions. Because of the immaturity of their psychological development and variability in their emotions, psychological conflicts often arise when they are faced with a problem of physiological, psychological, and social adaptation (1). Fear, anxiety, and other negative emotions are more likely to occur in a sudden, life-threatening, and uncertain situation. Young people subjected to social isolation measures during the COVID-19 pandemic period were forced to leave their friends and school environments (2). In China in January 2020, and then in the United States, Italy, Spain, England, and Turkey, among many others, distance education has replaced in-class education in many universities. Young people, who usually have an active lifestyle, have suddenly started to spend most of the day on computers and smartphones. Young people, who already spend most of their time on digital platforms, have increased their screen time with distance education. It is stated that this situation will create a basis for further increase in internet addiction in youngsters (4). The impact of the COVID-19 epidemic on university students in China, an increase in anxiety and depression levels has been reported in university students due to social isolation (5). In additionaly studies have shown that depressed people are more likely to suffer from social media addiction. For example, depression has been shown to be positively associated with Facebook addiction (6) and mobile phone addiction (7). Despite the positive effects of social isolation on the spread of the disease, the potential increase in sedentary behavior due to isolation can be harmful to health (8). Especially increased sitting time decreases regular physical activity, which, in addition to the development of chronic health problems (9), can lead to an increase in anxiety, stress, and depression, and a decrease in mental health and psychological vitality (10).

There exist few studies on the mental health conditions and internet addiction of university students who are subjected to the pandemic. Although there are studies examining the physical activity levels of university students during the pandemic period (11), there exists no study regarding the relationship between depression, internet addiction, and physical activity levels during social isolation periods due to the pandemic. 
In this study, it was aimed to examine the relationship between physical activity levels, internet addiction, and depressive symptoms in university students exposed to social isolation during the COVID-19 pandemic.

\section{Materials and Methods}

\section{Study Design and Setting}

This cross-sectional study was conducted in students at Aydın Adnan Menderes University Söke Health Services Vocational School between July and August 2020. The participants eligible for inclusion were students who agreed to participate in the research by giving verbal consent and filled the forms completely. We excluded individuals who had disabilities, language problems and not internet access.

\section{Sampling Description}

The total number of students registered at the school was 640. A minimum sample size of 138 students was calculated using the G*Power v.3.1 software based on previous research (12) and assuming a $95 \%$ statistical power, $\alpha=0.05$ with type 1 error frequency, and 0.3 effect size. Due to the possibility of $15 \%$ loss, 160 students were planned to include in the study. Students were randomly selected from their attendance lists.

\section{Data Collection and Processing}

A semi-structured questionnaire form was used to collect data from students by sending questionnaires to their e-mail addresses. Each student was given a due date to return the questionnaire. If the questionnaire was not returned by the deadline, or an incomplete questionnaire was returned, the questionnaire was sent again. After this reminder, all of the students returned the questionnaire.

The questionnaire form consisted of four major sections: 1) Personal Identification Form, 2) Short Form of Young's Internet Addiction Test (YIAT-SF), 3) Beck Depression Scale (BDS), 4) The International Physical Activity Questionnaire (IPAQ).

\section{Personal Identification Form}

This form included questions about students' age, sex, education, height, weight, place of residence, presence of a diagnosed disease, medication use, presence of any disability, time spent sitting during the day and night, day sleep times, time spent in front of TV, time spent on social media, time spent at home, presence of changes in weight during COVID-19, and regular exercise status before the pandemic.

\section{Short Form of Young's Internet Addiction Test}

YIAT-SF consists of 12 items on a 5-point Likert scale ranging from 1 (rarely) to 5 (always). The total score of the test ranges from 12 to 60 and represents an individual's tendency to internet addiction. In this study, we used a Turkish adaptation of the test (13).

\section{Beck Depression Scale}

The severity of depressive feelings was evaluated by the BDS. The Turkish adaptation of the scale was performed by Aydemir and Köroğlu (14). This scale consists of 21 questions, each with four possible answers (score: 0-3). Higher total scores indicate increased depressive symptoms [minimum ( $\mathrm{min}$ ): 0 , maximum ( $\max$ ): 63]. Cut of point was determined as 17.

The International Physical Activity Questionnaire

The Turkish adaptation of the scale was performed by Karaca and Turnagöl (15). Following standard IPAQ procedures, the number of days was multiplied by the number of hours reported for each component in order to calculate metabolic equivalent (MET) scores. Activity categories (inactive, active, and very active) were determined based on the total MET scores. Those who were not designated as active and very active were considered to be inactive.

\section{Statistical Analysis}

The SPSS software version 25.0 (IBM SPSS Statistics for Windows, Version 25.0. Armonk, NY, USA) was used for statistical analysis. The variables were investigated using visual (histograms, probability plots) and analytical methods (Kolmogorov-Smirnov/ShapiroWilk's test) to determine whether or not they are normally distributed. After examining the normality of distributions of the responses, descriptive statistics are presented as means \pm standard deviation (min-max) and median values for continuous variables and as percentages for the categorical variables. Correlation between depression and internet addiction scores were analyzed by Spearman correlation statistics. The relationship between depression and internet addiction scores between inactive and active students was evaluated with the Student's t-test. A 5\% type 1 error level was used to infer statistical significance. 


\section{Ethical Issues}

This research was conducted in adherence to the Declaration of Helsinki. Prior to the research, the students provided their informed consent and participated in the study on a voluntary basis. The study was approved by Faculty of Medicine NonInvasive Clinical Research Ethics Committee of a Aydın Adnan Menderes University in Turkey (protocol no: 2020/95, date: 04.06.2020). The participants were informed about the objectives of the study and that their confidentiality would be respected and their responses would not be judged.

\section{Results}

It was found that $63.8 \%$ of the participants were women, $97.5 \%$ were living with their families, $98.8 \%$ were associate degree graduates, and $96.3 \%$ did not have a physician-diagnosed disease and did not use any drug regularly.

As seen in Table 1, the mean body mass index was within normal limits. When the BDS and YIAT-SF lower and upper limit values were considered, it was seen that the mean BDS was quite low and the mean YIATSF was moderate.

As shown in Table 2, the students stated that they were at home for an average of $87.3 \pm 35.0$ days from the beginning of the pandemic until the date of the study; $5.6 \%$ were obese and $15.6 \%$ were overweight according to their declared weight and height measurements. It was found that $38.1 \%(n=61)$ of the university students sleep during the day and the average sleeping time during the day was $3.8 \pm 2.4$ (1-12) hours; the average sleeping time at night was 7.0 \pm 2.2 (0-10) hours; the time spent sitting during the day was $7.3 \pm 3.0$ (1-16) hours; the time spent in front of the television was $1.5 \pm 1.6(0-10)$ hours; and, the time spent on the computer/phone was $4.7 \pm 2.6$ (015) hours.

According to the IPAQ, $71.8 \%$ of the students were inactive, and only $28.2 \%$ of them were active or highly active during the restriction period. Depressive symptoms were present in $12.5 \%$ of the students. A moderately significant positive correlation was found between the students' mean scores for internet addiction and depression scores $(r=0.303 ; p<0.01)$. The mean internet addiction score of the students showing depression symptoms was $28.7 \pm 10.0$, and this value was $24.6 \pm 6.5$ for students showing no symptoms of depression ( $t=2.445 ; p=0.016)$. The addiction score was higher in students with depression.

When the students who were active and those who were inactive were compared according to the IPAQ, no difference was found between the mean scores of depression and internet addiction $(p>0.05)$.

Table 1. The age and BMI characteristics of the participants and results of outcome measures $(n=160)$

\section{Variables}

Age (years)

$\mathrm{BMI}(\mathrm{kg} / \mathrm{m} 2)$

IPAQ (min/week)

BDS

YIAT-SF

SD: Standard deviation, BMI: Body mass index, min: Minimum, max: Maximum, BDS: Beck Depression Scale, YIAT-SF: Short Form of Young's Internet Addiction Test

Table 2. Changes in the daily activities of students during the social isolation period compared to pre-pandemic values

\begin{tabular}{|l|l|l|}
\hline Changes in daily activities & $\mathbf{n}$ & $\%$ \\
\hline Increase in mobile phone usage time & 125 & 78.1 \\
\hline Increase in time spent on computer games & 49 & 30.6 \\
\hline Increase in TV watching time & 61 & 38.1 \\
\hline Increase in internet usage time & 139 & 86.9 \\
\hline Changes in sleep habits & 104 & 65.0 \\
\hline Weight change (increase in 76 students, decrease in 28 students) & 106 & 66.3 \\
\hline
\end{tabular}

\section{Mean \pm SD (min-max)/median}

$20.1 \pm 1.3(17-27) / 20$

$22.5 \pm 5.2 / 21.5$

$2448.2 \pm 3868.7(130.5-31279.5) / 1272$

$8.8 \pm 6.6(0-37) / 8$

$25.1 \pm 7.2(12-47) / 24$ 
According to our research findings, the BDS mean score of the inactive students was $8.5 \pm 6.4$, while that of active students was $8.8 \pm 6.3(t=-0.218, p=0.828)$ (Figure 1); and inactive students' mean YIAT-SF score was 24.9 \pm 7.1 , while active students' mean YIAT-SF score was 26.1 $\pm 7.9(t=-0.925, p=0.357)$ (Figure 2$)$.

\section{Discussion}

Findings of this study showed that, $71.8 \%$ of the students were inactive in the early pandemic period and no difference between physically active and inactive students in terms of depression and internet addiction scores. There exists no research in the literature directly related to our research findings. It

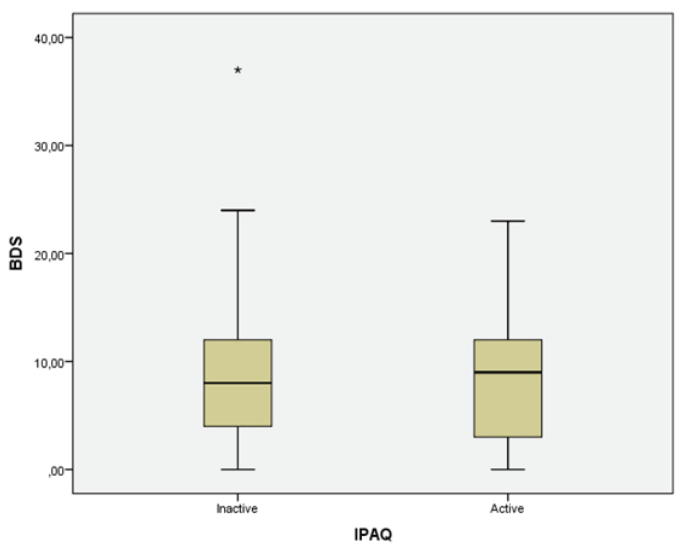

Figure 1. Distribution of depression scores according to students' activity status

BDS: Beck Depression Scale, IPAQ: International Physical Activity Questionnaire

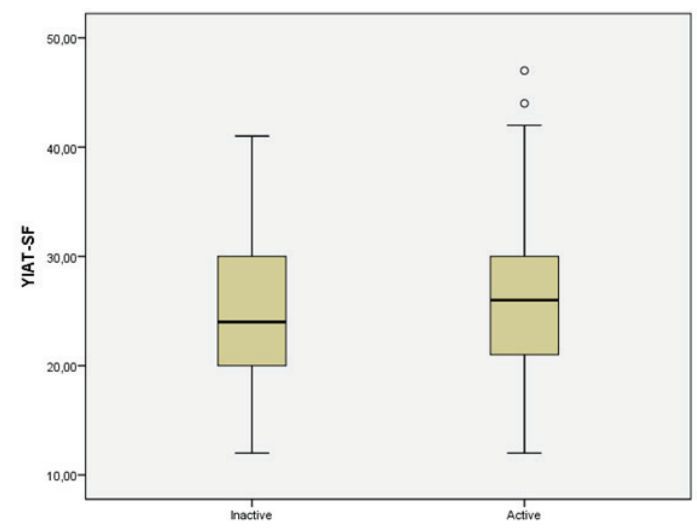

Figure 2. Distribution of internet addiction scores according to students' activity status

YIAT-SF: Short Form of Young's Internet Addiction Test was reported that the use of computers and electronic devices has increased due to the sedentary life style that comes with the pandemic (16). Sedentary life style is associated with depression (17). Since the beginning of the pandemic, researchers have noted a strong relationship between being physically active at home and being healthy and having a stronger immune system (9). Due to social isolation, working from home, attending distance education at home, and talking with friends or family members via the Internet, as opposed to face-to-face gatherings, have increased internet usage $(18,19)$. In studies examining the relationship between physical activity and internet addiction, it has been found that internet use is more common in people who do not perform regular physical activity (11). Due to the COVID-19 pandemic and related social isolation, physical activity in gyms or outdoor was restricted. While some perform webbased physical activities, physical activity levels have decreased in some segments with low social support and high anxiety about getting infected. Studies have reported that as physical activity increases, psychological distress decreases (20-22). Similarly, it has been reported that depressive symptoms decreased in those who performed moderate-tosevere physical activity during the pandemic (23). Xiang et al. (1) conducted a study in 1,396 university students, and reported that $52.3 \%$ of the students had low physical activity level and the depression rate was $41.8 \%$. Depressive symptoms were identified in $12.5 \%$ of the students in this study. Since the present study was conducted in the initial period of the pandemic, the short-term effects of restriction period were evaluated in this study. The higher rate in Chinese study, may be that the disease was first described in China and at the beginning of the pandemic, there were many unknowns about the disease that effected psychological well-being.

Another finding obtained in this study was that a moderately significant positive correlation was found between internet addiction scores and depressive symptom scores. Internet addiction scores were found to be higher in students with depressive symptoms. There are studies reporting similar results in parallel with our findings. In a study conducted with Chinese college students, it was determined that anxiety and depression were correlates for internet addiction (24). In a study conducted by Alaca (25), it was found that 
the students in the group with internet addiction had higher daily internet usage duration and depression scores compared to the group without internet addiction. In another study, dental students who were depressed were nearly six times more likely to be internet addicted than not-depressed students (26). In a study conducted by Fazeli et al. (27) in 1,512 students, internet addiction was found to cause disconnection from real life and increased insomnia, and as a result, it was reported that quality of life was affected, and internet addiction was found to be associated with depression and anxiety. Another study in Italy showed significant relationship between internet usage and depression in 809 university students (28). In this study, there was an increase in the internet usage of university students during the hours before bedtime. Due to the fact that education continues remotely with social isolation, university students who spend a significant part of the day on the computer or smartphone continue to use them after online course sessions. This situation causes irregularities in sleeping habits such as going to bed later and thus getting up later. Decrease in sleep quality has been associated with severe depression. Although sleep quality was not evaluated in our study, the change in sleep habits was declared by the students.

In this study, it was found that only $28.2 \%$ of the university students were active according to the IPAQ, and their mean depression score was $8.8 \pm 6.6(0-37)$ and mean internet addiction score was $25.1 \pm 7.2$. In addition, it was concluded that there was an increase in durations of TV watching, mobile phone usage, computer game playing, and internet usage. RomeroBlanco et al. (29) sitting time during the day among university students increased during the COVID-19 period. As physical activity plays an important role in reducing the pressure not only on the body but also on the mind, its importance has elevated especially during the pandemic (30).

In studies conducted before COVID-19, the rate of internet addiction among university students was determined to be $3 \cdot 2-6 \%(31,32)$. However, it was found between $7.7 \%$ and $24.4 \%$ in studies conducted during the COVID-19 outbreak $(8,24)$. Since the YIATSF was used in our study and there was no cut-off point, the frequency of internet addiction in students was not obtained. In the COVID-19 process, it is reported that internet usage rates have increased all over the world, and internet addiction rates have also increased. Also, it was determined that anxiety and depression were correlated with internet addiction (24). Compared to the pre-pandemic period, $86.9 \%$ of the students stated that there was an increase in their internet usage, $78.1 \%$ had an increase in mobile phone usage, and $65 \%$ had a change in their sleep habits. Being aware of the screen time, and regulating it (balanced use) is required. World Health Organization has established general health guidelines for the staying home period that includes useful tips for physical activity, mental health, internet addiction (33). There is a need for such guidelines for young people as well.

Since this study was planned and carried out with after onset of the COVID-19 pandemic, the fact that the participants' pre-pandemic physical activity status, depressive symptoms, and internet addiction rates were not known was a limitation of the study. After the pandemic, the change in the students' daily living activities could only be recorded according to their self-reports. In addition, it should not be noted that the findings obtained are short-term results since the study was conducted right after the first trimester of the pandemic.

\section{Conclusion}

This study showed that there was no difference between physically active and inactive students in terms of depression and internet addiction scores. However, in our study conducted at the beginning of the COVID-19 process, the average score of students with depression symptoms was found to be higher than those without depression symptoms. This finding provides further evidence of the association between depression symptoms and internet addiction in adolescents, and emphasizes the need to provide supportive online training (digital training videos, etc.) with a multidisciplinary approach to improve the mental and physical health of these young people.

\section{Ethics}

Ethics Committee Approval: The study was approved by Faculty of Medicine Non-Invasive Clinical Research Ethics Committee of a Aydın Adnan Menderes University in Turkey (protocol no: 2020/95, date: 04.06.2020). 
Informed Consent: The participants were informed about the objectives of the study and that their confidentiality would be respected and their responses would not be judged.

Peer-review: Externally peer-reviewed.

\section{Authorship Contributions}

Concept: N.Ö., Design: E.G.Ö., N.Ö., Supervision: E.G.Ö., Data Collection or Processing: N.Ö., Analysis or Interpretation: F.A., Literature Search: N.Ö., Writing: F.A., N.Ö., Critical Review: E.G.Ö., F.A.

Conflict of Interest: No conflict of interest was declared by the authors.

Financial Disclosure: The authors declared that this study received no financial support.

\section{References}

1. Xiang $M Q$, Tan $X M$, Sun J, Yang HY, Zhao XP, Liu L, et al. Relationship of Physical Activity With Anxiety and Depression Symptoms in Chinese College Students During the COVID-19 Outbreak. Front Psychol 2020; 11: 582436.

2. de Figueiredo CS, Sandre PC, Portugal LCL, Mázala-de-Oliveira T, da Silva Chagas L, Raony Í, et al. COVID-19 pandemic impact on children and adolescents' mental health: Biological, environmental, and social factors. Prog Neuropsychopharmacol Biol Psychiatry 2021; 106: 110171.

3. Anjum S, Ullah R, Rana MS, Khan HA, Memon FS, Ahmed Y, et al. COVID-19 Pandemic: A Serious Threat for Public Mental Health Globally. Psychiatr Danub. 2020; 32: 245-50.

4. Liu X, Liu J, Zhong X. Psychological state of college students during COVID-19 epidemic. 03.10.2020; Retrieved from SSRN: https:// ssrn.com/abstract=3552814 or http://dx.doi.org/10.2139/ ssrn. 3552814 .

5. Cao W, Fang Z, Hou G, Han M, Xu X, Dong J, et al. The psychological impact of the COVID-19 epidemic on college students in China. Psychiatry Res 2020; 287: 112934.

6. Lissak G. Adverse physiological and psychological effects of screen time on children and adolescents: Literature review and case study. Environ Res 2018; 164: 149-57.

7. Park SY, Yang S, Shin CS, Jang H, Park SY. Long-Term Symptoms of Mobile Phone Use on Mobile Phone Addiction and Depression Among Korean Adolescents. Int J Environ Res Public Health 2019; 16: 3584.

8. Jia P, Zhang L, Yu W, Yu B, Liu M, Zhang D, et al. Impact of COVID-19 lockdown on activity patterns and weight status among youths in China: the COVID-19 Impact on Lifestyle Change Survey (COINLICS). Int J Obes (Lond) 2021; 45: 695-9.

9. Chen P, Mao L, Nassis GP, Harmer P, Ainsworth BE, Li F. Returning Chinese school-aged children and adolescents to physical activity in the wake of COVID-19: Actions and precautions. J Sport Health Sci 2020; 9: 322-4.
10. Wathelet M, Duhem S, Vaiva G, Baubet T, Habran E, Veerapa E, et al. Factors Associated With Mental Health Disorders Among University Students in France Confined During the COVID-19 Pandemic. JAMA Netw Open 2020; 3: e2025591.

11. Islam MS, Sujan MSH, Tasnim R, Ferdous MZ, Masud JHB, Kundu $S$, et al. Problematic internet use among young and adult population in Bangladesh: Correlates with lifestyle and online activities during the COVID-19 pandemic. Addict Behav Rep 2020; 12: 100311.

12. Soydan MZ. Üniversite öğrencilerinin internet bağımlılığı ile depresyon ve yaşam doyumu arasındaki ilişki. (Uzmanlık Tezi). Haliç Üniversitesi. 2015; İstanbul.

13. Kutlu $M$, Savcı $M$, Demir $Y$, Aysan F. Young internet bağımlılığı testi kısa formunun Türkçe uyarlaması: Üniversite öğrencileri ve ergenlerde geçerlilik ve güvenilirlik çalışması. Anadolu Psikiyatri Der 2016; 17: 69-76.

14. Aydemir Ö, Köroğlu E. Psikiyatride kullanılan klinik ölçekler. İstanbul: Hekimler Yayın Birliği; HYB Yayınları; 2009.

15. Karaca A, Turnagöl HH. Çalışan bireylerde üç farklı fiziksel aktivite anketinin güvenirliği ve geçerliliği. Spor Bilimleri Derg 2007; 18: 68-84.

16. Prince SA, Melvin A, Roberts KC, Butler GP, Thompson W. Sedentary behaviour surveillance in Canada: trends, challenges and lessons learned. Int J Behav Nutr Phys Act 2020; 17: 34.

17. Wang $X, L i Y$, Fan $H$. The associations between screen time-based sedentary behavior and depression: a systematic review and meta-analysis. BMC Public Health 2019; 19: 1524.

18. Sandvine. The Global Internet Phenomena Report COVID-19 Spotlight. May 2020. Available from URL: https://www.sandvine. com/ covid-internet-sportlight-report.

19. OECD. Tackling coronavirus (COVID-19): Contributing to a global effort. COVID-19 global pandemic. 2020. Retrieved from https:// www.oecd.org/dac/development-assistance-committee/DACJoint-Statement-COVID-19.pdf.

20. Al-Tammemi AB, Akour A, Alfalah L. Is It Just About Physical Health? An Online Cross-Sectional Study Exploring the Psychological Distress Among University Students in Jordan in the Midst of COVID-19 Pandemic. Front Psychol 2020; 11: 562213.

21. Rodriguez-Ayllon M, Cadenas-Sánchez C, Estévez-López F, Muñoz $\mathrm{NE}$, Mora-Gonzalez J, Migueles JH, et al. Role of Physical Activity and Sedentary Behavior in the Mental Health of Preschoolers, Children and Adolescents: A Systematic Review and MetaAnalysis. Sports Med 2019; 49: 1383-10.

22. Qin F, Song Y, Nassis GP, Zhao L, Dong Y, Zhao C, et al. Physical Activity, Screen Time, and Emotional Well-Being during the 2019 Novel Coronavirus Outbreak in China. Int J Environ Res Public Health 2020; 17: 5170.

23. Stanton R, To QG, Khalesi S, Williams SL, Alley SJ, Thwaite TL, et al. Depression, Anxiety and Stress during COVID-19: Associations with Changes in Physical Activity, Sleep, Tobacco and Alcohol Use in Australian Adults. Int J Environ Res Public Health 2020; 17: 4065. 
24. Shen Y, Meng F, Xu H, Li X, Zhang Y, Huang C, et al. Internet addiction among college students in a Chinese population: Prevalence, correlates, and its relationship with suicide attempts. Depress Anxiety 2020; 37: 812-21.

25. Alaca N. The impact of internet addiction on depression, physical activity level and trigger point sensitivity in Turkish university students. J Back Musculoskelet Rehabil 2020; 33: 623-30.

26. Kumar S, Kumar A, Badiyani B, Singh SK, Gupta A, Ismail MB. Relationship of internet addiction with depression and academic performance in Indian dental students. Clujul Med 2018; 91: 300-6.

27. Fazeli S, Zeidi IM, Lin CY, Namdar P, Griffiths MD, Ahorsu DK, et al. Corrigendum to "Depression, anxiety, and stress mediate the associations between internet gaming disorder, insomnia, and quality of life during the COVID-19 outbreak" [Addict. Behav. Rep. 12 (2020) 100307]. Addict Behav Rep 2020; 12: 100322.

28. Cellini N, Canale N, Mioni G, Costa S. Changes in sleep pattern, sense of time and digital media use during COVID-19 lockdown in Italy. J Sleep Res 2020; 29: e13074.
29. Romero-Blanco C, Rodríguez-Almagro J, Onieva-Zafra MD, ParraFernández ML, Prado-Laguna MDC, Hernández-Martínez A. Physical Activity and Sedentary Lifestyle in University Students: Changes during Confinement Due to the COVID-19 Pandemic. Int J Environ Res Public Health 2020; 17: 6567.

30. Gilat R, Cole BJ. COVID-19, Medicine and Sports. Sports Med Arthrosc Rehabil 2020; 2: e175-6.

31. Lin MP. Prevalence of Internet Addiction during the COVID-19 Outbreak and Its Risk Factors among Junior High School Students in Taiwan. Int J Environ Res Public Health 2020; 17: 8547.

32. Pratama GB, Widyanti A. Internet addiction among Indonesia university students: Musculoskeletal symptoms, physical and psychosocial behavior problems.IOP Conf Ser Mater Sci Eng 2019; 528.

33. World Health Organization. \#HealthyAtHome. Retrieved from https://www.who.int/news-room/campaigns/connecting-theworld-tocombat coronavirus/healthyathome 2020. 